Maurer School of Law: Indiana University

Digital Repository @ Maurer Law

1989

\title{
Enforcing the Rules of Criminal Procedure: An American Perspective
}

Craig M. Bradley

Indiana University Maurer School of Law

Follow this and additional works at: https://www.repository.law.indiana.edu/facpub

Part of the Comparative and Foreign Law Commons, Criminal Procedure Commons, and the Legal Remedies Commons

\section{Recommended Citation}

Bradley, Craig M., "Enforcing the Rules of Criminal Procedure: An American Perspective" (1989). Articles by Maurer Faculty. 1346.

https://www.repository.law.indiana.edu/facpub/1346

This Article is brought to you for free and open access by the Faculty Scholarship at Digital Repository @ Maurer Law. It has been accepted for inclusion in Articles by Maurer Faculty by an authorized administrator of Digital Repository @ Maurer Law. For more information, please contact rvaughan@indiana.edu. 


\title{
ENFORCING THE RULES OF CRIMINAL PROCEDURE: AN AMERICAN PERSPECTIVE
}

\author{
Craig M Bradley*
}

\section{INTRODUCTION}

A recent submission to the Senate Standing Committee on Constitutional and Legal Affairs said this about the Australian law of criminal procedure:

The recent law of criminal investigation is governed by a confusing "amalgam of common law, statutory law, court-directed practices and internal police regulations" ... A A policeman's non-observance of [a citizen's rights] may lead to internal disciplinary procedures, but it does not constitute an offence nor give the suspect a cause of action [or, necessarily lead to exclusion of the evidence].'

Several months of studying the law of criminal investigation in Australia have led me to agree with this conclusion. It is the purpose of this article to discuss what that law is, but to do so in the only context that has any meaning in the real world of law enforcement. That is, in the context of remedies, specifically exclusionary remedies, for police misconduct. As the United States Supreme Court has observed, without a requirement that illegally obtained evidence must be suppressed, the constitutional prohibition against "unreasonable searches and seizures" is no more than "a form of words, valueless and undeserving of mention in a perpetual charter of human liberties". ${ }^{2}$ Thus, the Supreme Court, basing its decision in part on the fact that a majority of the states already had a mandatory exclusionary rule, ${ }^{3}$ required all states to exclude evidence obtained as a result of police misconduct. A recent study has concluded that "the exclusionary rule has acted as a strong institutional deterrent prompting the [Chicago] police department, the State attorney's office, and the local narcotics courts to develop programs and procedures designed to ensure compliance with the Fourth Amendment" ${ }^{4}$

It is irrelevant what judicial or statutory admonitions may be declared to govern the police. If these admonitions are not backed up by a consistently applied system of remedies for non-compliance, then they are nothing but

\footnotetext{
* Senior Fulbright Scholar, Australian National University. Professor of Law, Indiana University (Bloomington) School of Law. The author wishes to express his appreciation to the Faculty of Law, Australian National University for their hospitality and helpfulness and to the Australian-American Educational Foundation for their financial support of this venture. Particular thanks to David Feldman, Geoff Lindell and Peter Waight for their helpful comments on an earlier draft of this article.

1 Submission by the Victorian Council of Civil Liberties Inc, 22 July 1985, in Senate Standing Committee on Constitutional and Legal Affairs, A Bill of Rights for Australia? (1985) 154 (quoting P Sallmannn and J Willis, Criminal Justice in Australia (1984) 19). Sallmann and Willis continue: " $[1] n$ a sphere of activity involving issues of fundamental human liberty the governing rules are unclear, uncertain, out-of-date, difficult to find and understand and thus quite . . . unsuitable for the age in which we live": ibid 20.

2 Mapp v Ohio 367 US 643, 660 (1961).

3 Ibid 651.

${ }^{4} \mathrm{M}$ W Orfield, Jr "The Exclusionary Rule and Deterrence: An Empirical Study of Chicago Narcotics Officers" (1986) $54 \mathrm{U}$ Chi L Rev 1016, 1017. This squares with my own experience as a prosecutor in Washington, DC. The study further concludes that "judicial suppression, and the actions that police officials take in response to suppression 'punish' officers for conducting illegal searches": ibid 1027-1028. The police themselves seem to agree that the exclusionary rule is a good thing: ibid 1051 .
} 
empty words. ${ }^{5}$ In 1977, Justice Lucas, studying the behaviour of the Queensland police, had this to say:

In the ... cases of oppressive conduct discussed ... we see one factor common to all, that is the exercise of personal power undisturbed by thoughts that there will ever be an accounting for its use. ${ }^{6}$

While it is certainly the case in Australia that police abuses of a citizen's rights are the exception rather than the rule, still, the uneasy feeling persists, kindled by newspaper reports ${ }^{7}$ and commissions of inquiry, ${ }^{8}$ that, when the police want to run roughshod over rights they feel that they may do so with impunity. This is so both because the rights, and the remedies for the violations of these rights, are in no sense made clear, either to the police or the citizenry. As one Australian judge put it, "it is useless to complain of police overstepping the mark if it takes a day's research to find out where the mark is". ${ }^{9}$ This said, it is the goal of this article to try to set out, insofar as they can be set out, the Australian 'rules' concerning evidentiary exclusion as they pertain to violations of the rights against self-incrimination and unreasonable search and seizure, to offer a comparison to the American approach to these areas, and to discuss some of the proposals for reform that have been offered.

5 The Australian Law Reform Commission, (Report No 2 An Interim Report) Criminal Investigation (1975) para 287 (cited subsequently as LRC Criminal Investigation) agrees: "Rights without remedies may be no more than rhetoric; duties without sanctions for their breach may as well not be imposed. ... [T] he great failing of criminal procedure hitherto has not so much been its principles ... but rather the failure of the law on the ground to conform with the law on the books."

6 Report of the Board of Inquiry into the Enforcement of Criminal Law in Queensland (cited subsequently as the Lucas Report) (1977) 91.

7 Two examples of police conduct that would have 'shocked the conscience' of American courts were reported in the Canberra Times. In the first, Melbourne "police completely demolished a house yesterday in a search for clues to the Walsh Street police murders, but found nothing". This was done on the authority of a bankruptcy judge after the owners of the house were evicted; (they had not kept up their mortgage payments, apparently because they were in custody): the Canberra Times 6 January 1989, p 4.

The second case is bizarre: "Armed and hooded police burst into an outer Brisbane home, fired stun grenades, tied up the owner and then realised they had raided the wrong house". The owner, a 55 year old pensioner reported that "three masked men had dragged him at gunpoint into the lounge ... and tied him up with tape". "They threatened to kill anyone who moved," he said. Moreover, they bulldozed the front fence. All this, not in a search of a mass murderer, but for a "dangerous bank robber". No mention of a warrant appears in the article: the Canberra Times 15 January 1989, p 2. This debacle was widely reported in the newspapers and was obviously considered extremely bad form on the part of the police. However, the impression I got was that it wasn't the police conduct per se that was considered so outrageous, but only that they had the wrong house.

8 In addition to the Lucas Report, supra $\mathrm{n}$ 6, see also, Report of the Board of Inquiry into Allegations Against Members of the Victoria Police Force (1978) (cited subsequently as the Beach Report); LRC Criminal Investigation, supra n 5; Australian Law Reform Commission (Report No 38), Evidence (1987) (cited subsequently as $L R C$ Evidence).

9 Mr Justice M D Kirby, "Controls Over Investigation of Offences and Pre-trial Treatment of Suspects: Criminal Investigation and the Rule of Law" (1979) 53 ALJ 626, 651, quoting Lord Devlin "Police Powers and Responsibilities: Common Law, Statutory and Discretionary" (1967) 21 Australian Police Journal 112, 122. 


\section{EXCLUSIONARY RULES}

\section{A General Observations}

Australia does have a considerable body of law relating to evidentiary exclusion due to irregularities in the conduct of an investigation by the authorities. ${ }^{10}$ However, it is not so well developed that it could be considered an 'exclusionary rule'. That is, as previously mentioned, the police have no particular expectation that if they break the rules, the evidence will be lost. Such exclusion does sometimes occur but, as the Australian Law Reform Commission observed in 1975, if unlawfully obtained evidence "is relevant it is almost invariably admitted into evidence"." As a result of later court decisions, a more recent commentator has been a bit more positive about the situation, ${ }^{12}$ but it still seems to be the case, as the Lucas Report observed, that Australian police are, in general, "undisturbed"13 by fear of evidentiary exclusion, or any other remedy ${ }^{14}$ for rights violations.

The notion that "it matters not how you get [evidence]; if you steal it even, it would be admissible in evidence," 15 reflects the British common law. ${ }^{16}$ However, in Bunning $v$ Cross $^{17}$ a majority of the High Court made it clear that Australian law had broken from the British law and now concerned itself with "the undesirable effect of curial approval, or even encouragement, being given to the unlawful conduct of [police]". ${ }^{18}$ This point, as the New South Wales Law Reform Commission observed in 1979, and as is still true

10 Thus the Australian position offers some further disproof of the belief of American conservatives, as expressed by former Chief Justice Burger that the exclusionary rule is "unique to American jurisprudence": Bivens $v$ Six Unknown Named Agents of the Federal Bureau of Narcotics 403 US 388, 415 (1971) per Burger CJ, dissenting. I have previously punctured this claim in C M Bradley, "The Exclusionary Rule in Germany" (1983) 96 Harv L Rev 1032. Canada has also recently adopted a rule of evidentiary exclusion due to police misconduct.

11 LRC Criminal Investigation, supra n 5, para 210.

12 E Johnston, "The Exclusionary Rule and Other Controls Over the Abuse of Power by Police" (1980) 54 ALJ 466, 467: "[I]t is the strong impression of this writer that over recent years there has, at least in some jurisdictions, been a greater readiness on the part of judges to exercise their discretion against admission".

13 The Lucas Report, supra n 6, 91.

14 The other major legal sanctions are civil suits and non-public police disciplinary procedures. These sanctions are "notoriously least effective in the area of interrogation of suspects and the gathering of evidence in relation to crime": E Johnston, supra n 12, 466. "The weaknesses of these remedies ... are such that if continued in their present form they would render irrelevant, in terms of their practical effect [any reform of the rules of criminal procedure]": $L R C$ Criminal Investigation, supra $\mathrm{n} 5$, paras $210,258-260$. The reason that internal disciplinary procedures don't work is simple: these procedures punish bad police work. Without an exclusionary rule, police practices that are aggressive and obtain evidence by infringing on civil rights are not considered 'bad police work' by police review boards. Only if evidence obtained in this way is rendered unavailable to the prosecution's case do such practices become 'bad'. See M W Orfield, Jr, supra n 4, explaining how this works in Chicago.

$15 R v$ Leathan (1861) 8 Cox CC 498,501 .

16 Under British common law the only discretion in the trial court to reject such evidence would be on the ground that its use in court would be unfair (that is, prejudicial) to the accused: Kuruma $\vee R$ [1955] AC 197. See discussion in Bunning $v$ Cross (1978-79) 141 CLR 54.

17 (1978-79) 141 CLR 54, 73 per Stephen and Aickin JJ, Barwick CJ agreeing: "[T]he law in Australia now differs somewhat from that in England".

18 Ibid 74. 
a decade later, has not been fully grasped by the Australian legal profession and judiciary. ${ }^{19}$

\section{B Mandatory Exclusion}

The first basis for evidentiary exclusion is the long established common law rule, based on concerns of reliability, that statements that have not been voluntarily given must be suppressed. This rule was summarised in 1948 by Dixon $\mathrm{J}$ in McDermott $v R$ :

If he [the accused] speaks because he is overborne his confessional statement cannot be received in evidence and it does not matter by what means he has been overborne. If the statement is the result of duress, intimidation, persistent importunity, or sustained or undue insistence or pressure, it cannot be voluntary. It is also a definite rule of the common law that a confessional statement cannot be voluntary if it is preceded by an inducement held out by a person in authority and the inducement has not been removed before the statement was made. ${ }^{20}$

The burden of proof is on the prosecution to show, on the "balance of probability', that the statement was voluntary. ${ }^{21}$ Despite frequent mention of this rule in High Court decisions, it has rarely been invoked. ${ }^{22}$ There is no other mandatory rule of exclusion generally applicable in Australia.

In New South Wales, however, there is a statutory requirement that, in addition to the above-stated rules, no confession may be received into evidence if it has been induced by any "untrue representation", made to the defendant by the authorities. ${ }^{23}$ By contrast, a Victorian statute specifically cuts back on the common law rule of McDermott, providing that a 'confession' should not be inadmissible if induced by "promise or threat", "unless ... that

19 New South Wales Law Reform Commission, Working Paper Illegally and Improperly Obtained Evidence (1979) paras 22-25. See discussion infra text at nn 117-136.

20 (1948) 76 CLR 501, 511. E Johnston, supra n 12, 466-467, adds: "It has been held that "overborne" in the above statement means externally overborne, not overborne by internal pressures or internal motives (for example, desire to obtain bail, not induced by anything said by police)".

21 E Johnston, supra n 12, 467, citing dicta in Wendo $v R$ (1963) 109 CLR 559, 562 per Dixon CJ; 572, per Taylor and Owen JJ.

22 See Waight and Williams, Cases and Materials on Evidence (2nd ed 1985) 735, citing two Australian, plus a handful of other British Commonwealth cases over a period of 40 years, as "some of the very few reported cases where a confession has been excluded because of persistent police questioning". The Australian cases are $R \vee$ Burnett (1944) VLR 115 and $R v$ Jones [1970] 1 NSWR 190. In Jones, where the defendant had been interrogated for $171 / 2$ hours over a period of $283 / 4$ hours - including a 14 hour period of almost continuous questioning from $7.30 \mathrm{pm}$ to $9.30 \mathrm{am}$ the next day - the trial judge excluded the confession, not because it was involuntary but in the exercise of discretion. In $R v$ Fewster (Queensland Supreme Court, 23-26 April 1979, unreported decision of Kelly J) cited P Applegarth, "Police Malpractice: a judicial response" in J Basten (ed) The Criminal Injustice System (1982) 277), the defendant was hit in the mouth at time of arrest and told that "if he didn't give a statement the police officers would come down on him as hard as possible ...". The confession was excluded.

In addition, in two Queensland cases, confessions were suppressed on the ground that the police had offered the suspect an 'inducement' to confess. In $R \vee$ Plotzki [1972] Qd R 379 the Court of Criminal Appeals disallowed a confession made after the police suggested that the suspect would not be charged with a crime if he confessed. In $R v$ Beere [1965] Qd R 370 the Queensland Supreme Court disallowed a confession simply because the police had intimated to the suspect "that it would in some way be beneficial for her to tell the truth": ibid 371. See also, Waight and Williams, ibid 736-40 discussing other Commonwealth cases where evidence has been suppressed on this ground.

23 Crimes Act 1900 (NSW), s 410(1)(a) and (b). 
inducement was really calculated to cause an untrue admission of guilt to be made". ${ }^{24}$ The New South Wales provision goes beyond any requirement imposed by the United States Supreme Court. That Court has never directly considered the issue but it did, in one case, approve on other grounds the use of a confession that was induced by the police telling the suspect, falsely, that his fingerprints had been found at the crime scene. ${ }^{25}$ However, the New South Wales courts have not ever actually excluded a confession pursuant to this section ${ }^{26}$ in a reported decision, and have limited it to knowingly untrue statements by the police, made with the object of obtaining a confession from the suspect. 27

\section{Discretionary Exclusion}

Beyond the 'involuntariness' basis for exclusion, there are three other possible grounds, all of which lie in the discretion of the trial judge (who is at least obliged to consider whether that discretion should be exercised). ${ }^{28}$

\section{(I) Prejudicial Impact}

The first of these is self evident. It is that "a confession (and indeed any evidence tendered by the prosecution) can be rejected when its probative value is low and its prejudicial effect is high". ${ }^{29}$ I could find no reported instance of this discretion ever having been exercised, presumably because the probative value of a confession is almost invariably high.

\section{(2) Unreliability}

The second ground for discretion is that a confession, though not involuntary, may he excluded, if "it would be unfair to use it in evidence

24 Evidence Act 1958 (Vic), s 149. This provision has been read narrowly by the High Court in $R v$ Lee (1950) 82 CLR 133 which held that it was strictly limited to 'confessions' rather than other statements by the accused which might prove useful to the prosecution. And, it is limited to cases where the "common law would have rejected the confession as nonvoluntary on the sole ground that it was induced by such a threat or promise, not to cases in which the common law would have rejected it as non-voluntary on any other ground", ibid 150. See also Consultative Committee on Police Powers of Investigation, Report on $s 460$ of the Crimes Act of 1958 (Victoria 1986) 16.

The Australian Capital Territory has a similar provision: Evidence Act 1971, s 68(1), (2). The other States simply use the common law voluntariness test. See P Gillies The Law of Criminal Investigation (1982) 92-97.

25 Oregon v Mathiason 429 US 492, 495 (1977).

26 All of the New South Wales cases interpreting this section seem to have found the evidence admissible, eg because a false statement was not made for the purpose of obtaining a statement from an accused: $R \vee$ Thompson (1961) $62 \mathrm{SR}(\mathrm{NSW})$ 135; or because the false statement was made by an agent provocateur for the purpose of inducing the defendant to commit an offence rather than confessing to a previously committed offence: Feiler v McIntyre [1974] 2 NSWLR 268. See generally, Waight and Williams, supra $\mathrm{n} 22,742$.

$27 R v$ Thompson, supra $\mathrm{n} 26$.

$28 R$ v Ireland. (1971-72) 126 CLR 321, 335 per Barwick CJ.

29 Waight and Williams, supra n 22, 750. See eg Driscoll v $R$ (1977) 137 CLR 517, 541 per Gibbs J, Mason, Jacobs and Murphy JJ agreeing; $R v$ Gidley (1984) 3 NSWLR 168; 17273 per Hunt J; $R$ v Tellow (1986) 27 A Crim R 198, 200 per Burt CJ. (None of these cases involved the actual exclusion of confessional evidence on prejudice grounds; they simply stated the principle that it could be done.) 
against [the defendant]". ${ }^{30}$ There had been considerable confusion about whether this 'unfairness' referred to misconduct by the police or concerned the unreliability of the statement. ${ }^{31}$ Recently, however, a majority of the High Court made it clear that the latter circumstance was what concerned the Court:

Unfairness, in this sense, is concerned with the accused's right to a fair trial a right which may be jeopardised if a statement is obtained in circumstances which affect the reliability of the statement (emphasis added). ${ }^{32}$

Thus the Court has implicitly endorsed the earlier statement of Latham CJ that "examples of such unfairness would be afforded by irresponsibility by the accused on the occasion when the statement was made or failure on his part to understand and appreciate the effect of question and answers." ${ }^{33}$ This head of discretion would not apply to the finding of real evidence which could not be rendered unreliable by the means by which it was obtained. ${ }^{34}$ While court opinions refer to this discretion with relative frequency, ${ }^{35}$ I was however able to discover only two cases, both of lower courts, in which it was actually exercised.

In Klemenko v Huffa ${ }^{36}$ a single judge of the South Australian Supreme Court reversed the defendant's conviction for a summary offence of being in possession of stolen property on the ground that psychiatric testimony showed that he was insane at the time he gave his statement to the police and the magistrate had not considered whether or not to exercise his discretion. ${ }^{37}$ In a study of all indictable cases that were concluded in the Sydney District Courts in a six week period there was, among the 147 cases, one (unreported) in which the judge excluded the confession of a defendant,

30 McDermott $v R$ (1947-48) 76 CLR 501, 506-7 per Latham CJ, 517 per Williams $J ; R v$ Lee (1950) 82 CLR 133, 154-55 (unanimous judgment).

31 P Gillies, supra n 24, 101: "[I]t will be apparent that an element of ambiguity has been introduced into this branch of the law." See discussion at 102-104.

32 Van der Meer $v R$ (1988) 82 ALR 10, 26 per Wilson, Dawson and Toohey JJ.

33 McDermott v $R$ supra n 30, 507. See also Ostojic v $R$ (1978) 18 SASR 188,197 per Wells $\mathrm{J}$, (Hogarth and King JJ agreeing): “. . I I can imagine cases in which a trial judge might exercise this discretionary power where no [police] impropriety existed. A suspect might be suffering hidden but naturally occurring pain, [or] he might have sustained severe shock ..... (But his Honour was less inclined to find that self-induced drunkeness might lead to an exercise of the discretion: $i d$.$) .$

In Duke v R(1989) 83 ALR 650, Brennan J further elaborated on his view of the 'unfairness' discretion: "The unfairness against which an exercise of the discretion is intended to protect an accused may arise not only because the conduct of the preceding investigation has produced a confession which is unreliable but because no confession might have been made if the investigation had been properly conducted. If, by reason of the manner of the investigation, it is unfair to admit evidence of the confession, whether because the reliability of the confession has been made suspect or for any other reason, that evidence should be excluded. Trickery, misrepresentation, omission to inquire into material facts lest they be exculpatory, crossexamination going beyond the clarification of information voluntarily given, or detaining a suspect or keeping him in isolation without lawful justification - to name but some improprieties - may justify rejection of evidence of a confession if the impropriety had some material effect on the confessionalist" (at 653). In my view, this statement is not helpful as it tends to confuse the 'unfairness' (unreliability) head of discretion with the 'police misconduct' head of discretion, discussed infra text at nn 30-31.

34 But see discussion of the third head of discretion, infra text at nn 48-107.

35 See, generally, P Gillies, supra n 24, 98-127 and cases discussed therein; Waight and Williams supra $\mathrm{n} 22,771-73$.

36 (1978) 17 SASR 549.

37 Ibid 557. 
heroin addict, who was "physically debilitated and under heavy medication" and exhibited a "very markedly clouded consciousness". ${ }^{8}$

Contrariwise, in several cases, the courts, including the High Court, upheld the admission of a confession where it would have seemed that it should have been excluded due to the defendant's incapacity. In Basto $\vee R^{39}$ the confession was admitted despite the fact that the defendant was suffering from an overdose of drugs (which he had taken for the purpose of committing suicide) and later the same day was deemed to be insane. In $R v$ Stareckito the defendant's statement had been taken after he had shot himself in the brain.

The American approach to the mentally unbalanced confessor has a different focus but will usually not allow use of the confession of an insane person. In Colorado $v$ Connelly ${ }^{41}$ the defendant had approached a policeman on the street and confessed to a murder. A psychiatrist testified that this confession was motivated by psychosis. ${ }^{42}$ The United States Supreme Court, reversing the Colorado Supreme Court, held that the confession was not excludable on Fifth Amendment ${ }^{43}$ grounds because the Fifth Amendment only prohibited "police wrongdoing" which was obviously not present in this case. ${ }^{44}$ That is, there was, in no sense, 'compelled self-incrimination', as forbidden by the Constitution.

The Supreme Court thus distinguished an earlier case, Blackburn $v$ Alabama, ${ }^{45}$ where the police had intensively interrogated an insane person to extract a confession. In Blackburn the Court ordered the confession excluded. Connelly did not present the issue of reliability because, having excluded the confession as 'involuntary', the trial court had made no finding as to reliability. ${ }^{46}$ The Supreme Court indicated that such inquiries should be left to State law. ${ }^{47}$ Under the laws of most States, a confession by an insane person would not be considered reliable and consequently could not be used. 48

38 N Stevenson, "Criminal Cases in the NSW District Court: a pilot study" in J Basten (ed) supra $\mathrm{n} 22,106,115$.

39 (1954) 91 CLR 628. See also Sinclair v $R$ (1946) 73 CLR 316 where the confession was admitted despite the fact that the defendant was considered insane.

40 [1960] VR 141. See also $R \vee$ Buchanan [1966] VR 9 (defendant suffering obvious head injuries sustained in automobile accident) and other cases cited in Waight and Williams, supra $\mathrm{n}$ $22,773$.

4155 USLW 4043 (1986).

42 Ibid 4044.

43 The Fifth Amendment to the United States Constitution provides, in pertinent part, "nor shall [any person] be compelled in any criminal case to be a witness against himself".

44 Supra n 41, 4045.

45361 US I99 (1960). The Court also distinguished Townsend v Sain 372 US 293 (1963) where the confession was excluded because police had injected a suspect with a 'truth serum'.

46 Supra n 41, 4050 per Brennan J, dissenting.

47 Supra $\mathrm{n} 41,4046$. The Court went on to hold, wrongly in my view, that the defendant was capable of making a voluntary waiver of his right to silence and could be interrogated further by the police after receipt of Miranda warnings. This flies in the face of the Blackburn holding that "a most basic sense of justice is affronted by ... incarcerating a human being on the basis of a statement he made while insane": supra n 45, 207 (at least where, as in Blackburn, he is questioned while insane).

48 See eg, Wharton's Criminal Evidence (4th ed 1986) 643: "A confession is inadmissible if the accused was mentally or physically incapacitated at the time." (However, mental retardation, as opposed to insanity, does not automatically bar a confession but is a factor to be considered in its admissibility.) 


\section{(3) Police Misconduct}

The final basis for discretionary exclusion of evidence in Australia is "when the evidence is the product of unfair or unlawful conduct on the part of the police". ${ }^{49}$ However, unlike in America, where the mere failure to give the Miranda warnings or to obtain a search warrant when appropriate will automatically result in evidentiary exclusion, ${ }^{50}$ in Australia the trial judge must weigh two competing requirements against each other: ". . . the desirable goal of bringing to conviction the wrongdoer and the undesirable effect of curial approval, or even encouragement, being given to the unlawful conduct of those whose task it is to enforce the law." 51 In $R v$ Ireland ${ }^{52}$ the High Court held that photographs of the defendant's hands, taken without consent, to allow an expert witness to evaluate whether scratches on the hand were caused by the handling of a knife with a damaged handle, should have been excluded from the defendant's murder trial. In Ireland the policeman told the suspect that he "had to" have his hands photographed.53 The court held that neither at common law nor under the relevant statute ${ }^{54}$ has a police officer power to require a person to submit himself to photography for any purpose other than identification, ${ }^{55}$ and that the photographs should have been excluded in the exercise of the trial court's discretion. ${ }^{56}$

As the High Court later made clear in Bunning $v$ Cross, 57 this head of discretion

by no means takes as its central point the question of unfairness to the accused. It is, on the contrary, concerned with broader questions of high public policy, unfairness to the accused being only one factor which, if present, will play its part in the whole process of consideration. ${ }^{58}$

These factors include regard for the "liberty of the subject" 59 and concern that the government not "play an ignoble part" "*o in the conviction of criminals. Thus, the concerns of respect for privacy, concern for the purity

49 Cleland v R (1982-83) 151 CLR 1,7 per Gibbs, CJ quoting Bunning $v$ Cross (1978-79) 141 CLR 54, 74-75 per Stephen and Aickin JJ; Barwick, CJ agreeing. "[the] principal area of operation [of this head of discretion] will be in relation to what might loosely be called 'real evidence', such as articles found by illegal search, recordings of conversations, the result of breathalyser tests, fingerprint evidence and so on."

50 Eg Miranda v Arizona 384 US 436, 444 (1966): "The prosecution may not use statements, whether exculpatory or inculpatory, stemming from custodial interrogation of the defendant unless [he has received the warnings]".

51 Bunning $v$ Cross (1978-79) 141 CLR 54, 74 per Stephen and Aickin JJ; cited in Cleland $v R(1982-83) 151$ CLR 1, 7 per Gibbs CJ.

52 (1971-72) 126 CLR 321.

53 lbid 327.

54 Police Offences Act 1,953 (SA), s 81.

55 Supra n 28, 334, per Barwick CJ, (McTiernan, Windeyer, Owen and Walsh JJ agreeing).

56 Ibid 335.

57 (1978-79) 141 CLR 54.

58 Ibid 74-75 per Stephen and Aickin JJ.

59 Ibid 78 per Stephen and Aickin JJ.

60 Id quoting Olmstead v United States 277 US 438, 470 (1928) per Holmes J, dissenting. 
of the judicial process and deterrence of police misconduct all figure in the Australian, as they do in the American, exclusionary rule. ${ }^{61}$

More specifically, the factors to consider include whether the "unlawful or improper conduct" 62 on the part of the police was intentional or reckless on the one hand or merely "accidental" or "unconscious" on the other; ${ }^{63}$ "the ease with which the law might have been complied with"; 64 the nature of the offence charged ${ }^{65}$ and whether there is evidence that the rule broken was one which reflected a "deliberate intent on the part of the legislature to narrowly restrict the police ...".66 The probative value of the evidence would be a factor to consider only in cases of a negligent police violation. ${ }^{67}$ In Bunning, by a 4 to 1 majority, the High Court reversed the magistrate's exercise of discretion and held that evidence of a breathalyser test would be admissible in a drunk driving case despite the fact that it had been taken without reasonable suspicion and without performing a preliminary roadside test as required by the statute. ${ }^{6}$ In $R v$ Williams the High Court upheld the trial judge's exercise of discretion in excluding the confession of a burglary suspect who had been arrested at 6.00 am on one day and not taken to the magistrate until 10.00 am the following day. "If an arrested person is detained, not for the purpose of enabling him to be brought before a justice, but for the purpose of questioning him, the detention will be unlawful."69 However, the Court did not hold that evidence must be excluded in such circumstances; it simply declined to consider whether the trial judge had inappropriately exercised his discretion in excluding the evidence. ${ }^{70}$

Both of these cases go beyond the constitutional requirements of fair procedure in the United States. It is quite clear there since Schmerber $v$ California $^{71}$ that the accused can be subjected to photographing, fingerprinting

61 Compare Weeks $v$ United States 232 US 383 (1914) (original case declaring exclusionary rule in Federal Courts) with United States $v$ Calandra 414 US 338 (1974) (assuming that deterrence of police misconduct is goal of American exclusionary rule). See S J Wasserstrom, "The Incredible Shrinking Fourth Amendment" (1984) 21 Am Crim L Rev 257 disputing the Court's current view.

62 Bunning v Cross (1978-79) 141 CLR 54, 74-75 per Stephen and Aickin JJ.

63 lbid 77 per Stephen and Aickin JJ.

$64 \mathrm{Id}$.

65 Ibid 79 per Stephen and Aickin JJ.

$66 \mathrm{Id}$.

67 Ibid 77 per Stephen and Aickin JJ. That is, if the police misconduct were intentional, the fact that the evidence was very significant to the prosecution's case would be irrelevant.

68 Ibid 71 per Stephen and Aickin JJ.

69 (1986) 161 CLR 278, 285 per Gibbs CJ.

70 lbid 285 per Gibbs, CJ; 302 per Mason and Brennan JJ (because this was a question of mixed law and fact, not open to the prosecution to appeal after an acquittal). This explains the seeming inconsistency with Cleland (1982-83) 151 CLR I, where the court upheld the admission of a confession of a defendant (though reversing the conviction on other grounds) who was arrested at $1.00 \mathrm{pm}$ and held until midnight, despite the trial judge's holding that it was unlawful to hold the defendant in custody after $5.30 \mathrm{pm}$ without taking him before a magistrate. See also $R v$ Salihos (1987) 27 A Crim R 319, upholding the admission of a confession obtained during a concededly illegal (because too extended) custody following a legal arrest on the ground that the police misconduct did not demonstrate a deliberate or reckless disregard of the law. The court noted that Williams did not require exclusion. In $R v$ Narula (1986) 22 A Crim $\mathrm{R} 409$ a confession obtained during an illegal delay was not excluded because the police were unaware of a pre-Williams Federal Court decision forbidding postponing taking the defendant before a justice until after the first interrogation.

71384 US 757 (1966). 
and the taking of blood, hair, urine, voice, ${ }^{72}$ and handwriting samples for the purpose of using the evidence thus discovered against him. ${ }^{73}$ The Ireland decision seems strange, in view of the general reluctance of the Australian courts to exclude evidence. Given the experience of the ensuing nineteen years, it must be regarded as an aberration on its facts. ${ }^{74}$ However, its basic recognition of the discretion to exclude real evidence due to police misconduct continues to be the law. ${ }^{75}$

Similarly to Williams, the United States Supreme Court has, in Mallory $v$ United States, ${ }^{76}$ struck down a conviction on the ground that a seven hour delay (which resulted in a confession) in taking the defendant before a magistrate violated the Federal Rule of Criminal Procedure requiring such an appearance without "unnecessary delay". ${ }^{77}$ However, this decision has never been applied to the states through the Constitution and has been 'reversed' by Congress. ${ }^{78}$

Unlike the Australian 'rules' of exclusion discussed earlier, the 'police misconduct' discretion is actually used from time to time, at least in confession cases, though not with any regularity or consistent logic. For example, the South Australian Supreme Court has been quite firm in enforcing an apparently "automatic discretionary exclusion" 79 where the police continue to question the defendant after he has asserted either his right to silence or to counsel. ${ }^{80}$ Queensland has a similar, though clearly not 'automatic' rule, ${ }^{81}$ at least as to assertion of the right to counsel. However, as one commentator has observed, "in the reported cases where (confessional] evidence was not admitted, there was evidence which strongly corroborated the accused's story". ${ }^{2}$ Thus these confessions may actually have been ordered excluded, not because of procedural irregularities, but because the courts believed that they were fabricated.

72 United States $v$ Dionisio 410 US 1, 5-7 (1973).

73 United States $v$ Wade 388 US 218, 223 (1967): "[The Fifth Amendment] offers no protection against compulsion to submit to fingerprinting, photography, or measurements, to write or speak for identification, to appear in court, to stand, to assume a stance, to walk or to make a particular gesture."

74 Most Australian state statutes provide for bodily examinations of persons in custody including the taking of blood and hair samples, so the issue is not likely to arise very often. See generally, P Gillies, supra n 24, 260-61. See too Ex parte Weldon (1971) 2 NSWLR 294 excluding breathalyser evidence obtained in violation of statute.

75 Cleland (1982-83) 151 CLR 1, 19-20 per Deane J.

76354 US 449, 455 (1957).

77 Federal Rules of Criminal Procedure Rule 5(a).

78 In 1968 Congress provided that such a delay alone would not be a basis for evidentiary exclusion but only a factor to consider in determining 'voluntariness': 18 USC 3501 (1968). (Congress could only do this because Mallory was grounded on the Congressionally enacted Federal Rules of Criminal Procedure, not on the Constitution.)

79 This oxymoronic characterisation is from Waight and Williams, supra n 22768.

$80 R$ v Stafford (1976) 13 SASR 392, $398-99$ per Bray CJ; $R v$ Killick (1979) 21 SASR 321; Walker $v$ Marklew (1976) 14 SASR 463; $R$ v Buckskin (1974) 10 SASR 1, 5 per Walters $\mathrm{J}$.

$81 R v$ Hart (1979) Qd R 8, 13 per Connolly J: “The circumstance that an accused person has been refused access to his solicitor will not render evidence of his subsequent interrogation legally inadmissible but it may well be a ground for the exercise of the discretion to reject his confession". The Court qualified this right of access to the solicitor to cases where "no unreasonable delay or hindrance is caused to the process of investigation ...."id. See also $R v$ Borsellino [1978] Qd R 507, 513 per Dunn J.

82 N Stevenson, supra n 38, 120. 
The High Court, while recognising the "clearly established judicial discretion'83 to exclude evidence in such a case, has indicated that such exclusion is not mandatory. ${ }^{84}$ In New South Wales, in the extraordinary case of $R v$ Merritt and $R o s 0^{85}$ a confession was admitted into evidence despite the fact that the accused had given the police a written declaration, drawn up by his solicitor, stating that he would only answer questions in the presence of a lawyer. The court upheld the trial judge's admission of the confession on the ground that the defendant had failed to prove that his written declaration had come to the attention of the interviewing (as opposed to the arresting) officers. ${ }^{86}$ The police claimed that it had not. ${ }^{87}$ Defendant's further claim that after being cautioned and asked if he understood the caution he replied "No, and you can tell him [another officer] to stop writing", was also rejected on the ground that it was equivocal. ${ }^{88}$

In America, the law on this issue is fairly clear. As is well known, before a defendant can be subjected to 'custodial interrogation' by the police he must be warned that he has a right to remain silent, that anything he says may be used against him, that he has a right to counsel, and that if he can't afford counsel, one will be provided free of charge. ${ }^{89}$ If the defendant indicates that he wishes to remain silent, questioning must cease. ${ }^{90}$ If he indicates that he wants a lawyer, questioning must cease until a lawyer is

83 Ireland supra $\mathrm{n} 28333$ per Barwick CJ.

84 Id. In Ireland, the Court cited Basto v $R$ (1954) 91 CLR 628, where it had approved the admission of such a statement in the discretion of the trial judge. See also $R v$ Lee (1950) 82 CLR 133, 157.

85 (1985) 19 A Crim R 360.

86 Ibid 375 per Hunt $\mathbf{J}$.

87 Ibid 372 per Hunt $J$. The court suggested that, even if this declaration had come to the attention of the interviewing officers it might not be relevant: ibid 375 .

88 Ibid 376 per Hunt J. The defendant further claimed that his confession had been fabricated by the police: ibid 372 . This allegation is frequently made in Australia, apparently with substantial basis. See discussion, infra text at nn 85-88; also, $R v$ Dugan (1970) 92 WN(NSW) 767 where the accused had been refused access to his solicitor who was elsewhere on the premises, but the evidence was admitted despite two judges deeming the police conduct "reprehensible"; and $R \vee$ Barron [1975] VR 496, 504 per Young CJ and Menhennitt J (defendant stated that he didn't want to answer questions; record of interview nevertheless admissible).

89 Miranda v Arizona 384 US 436 (1966).

90 Ibid 474. There is an exception to this principle recognised in Michigan $v$ Mosley 423 US 96 (1975) where the defendant, after being properly warned and questioned about Crime A, indicated that he didn't want to discuss it. Two hours later, a different detective, after warning the defendant, questioned him about Crime B. The defendant did not indicate that he wished to remain silent as to Crime B, and confessed. It is unclear whether Mosley is only applicable when two different crimes and two sets of police are involved or whether it would also apply to a resumption of questioning of a defendant by the same police as to the same crime. It is my impression that this issue doesn't often arise. That is, that the police and/or lower courts generally respect the defendant's assertion of the right to silence. See, eg Anderson v Smith 751 F 2d 96, 101 (1984); Robinson v Percy 738 F 2d 214, 220 (1984). (Both cases holding that subsequent questioning after an invocation of the right to silence was error and the defendant's responses should not have been admitted into evidence. Anderson's conviction was reversed but Robinson's was affirmed on the ground that the error was harmless.) 
provided. ${ }^{91}$ Any statements made by the defendant after invocation of these rights (or if the warnings have not been given) must be excluded from evidence. ${ }^{92}$ The fact that one policeman did not know that the defendant had asserted his rights to another policeman is irrelevant. ${ }^{93}$

In addition to the 'assertion of rights' cases, the problem of holding defendants for the purpose of interrogation has attracted judicial attention in Australia. As discussed, in Williams ${ }^{94}$ the High Court affirmed a trial court ruling that a confession should be excluded when obtained during an unnecessary delay in bringing the accused before a magistrate, enforcing a Tasmanian statute which reflected the common law requirement of such an appearance "as soon as practicable". 95 To the same effect was an earlier, unanimous, decision based on a Commonwealth statute, $R v$ Iorlano. ${ }^{96} \mathrm{~A}$ series of Victorian cases had similarly excluded confessional evidence based on s 460 of the Crimes Act 1958 (Vic) which required that arrestees be brought before a magistrate "as soon as practicable. ${ }^{97}$ This led the Victorian Parliament to amend s 460 to provide that the police could hold a suspect for up to six hours, rather than presenting him "as soon as practicable" before the magistrate; 98 but recently, the statute has been changed again allowing the police to hold the defendant for a "reasonable time" before presenting him. ${ }^{99}$

By the same token, some, but not all, Australian courts have held that the discretion to exclude evidence should be exercised when a confession is obtained from a defendant who is in illegal custody $a b$ initio. 100 It would seem to follow from Williams that if unduly extended custody should be

91 Miranda v Arizona 384 US 436, 474 (1966) and Edwards v Arizona 451 US 477 (1981). There is no exception similar to Mosley when the defendant has invoked his right to counsel. Arizona v Roberson 56 USLW 4590 (1988). However, if, after invocation of his right to counsel, the defendant 'initiates' further discussions with the police, his statements may be used against him: Oregon v Bradshaw 462 US 1039, 1044 (1983). The reason that the Court has given for treating the invocation of the rights to silence and counsel differently is that, in the latter case, the subject, by asking for counsel, is indicating that he can't deal with interrogation without assistance. In the former case, he is showing that he is in command of the situation and consequently is capable of making a reasoned decision whether to speak or remain silent in the face of subsequent questioning. Y Kamisar, "The Edwards and Bradshaw Cases: The Court Giveth and The Court Taketh Away" (1984) 5 Supreme Court: Trends and Developments 1982-83 153, argues that this distinction is untenable.

92 Miranda v Arizona 384 US 436, 476 (1966).

93 Arizona v Roberson 56 USLW 4590, 4593 (1988) per Stevens J.

94 (1986) 161 CLR 278.

95 lbid 285 per Gibbs CJ.

96 (1983) 50 ALR 291. Iorlano interpreted the Customs Act 1901 (Cth) which provided that an arrested person should be brought before the magistrate "without undue delay".

97 Eg $R v$ Carter (Vic County Court, 1983, unreported decision of Just J), $R v$ Stewart and Kent (Vic County Court, 1983, unreported decision of Just J), noted in Consultative Committee on Police Powers of Investigation, Report on $s 460$ of the Crimes Act of 1958 (Victoria 1986) 21; $R \vee$ Larson and Lee [1984] VR 559, 569 per Hampel J: "The conduct of the police demonstrated a flagrant disregard for the rights of the accused." Larson also involved a written statement from a solicitor that the accused had nothing to say to the police.

98 Crimes (Criminal Investigations) Act 1984 (Vic) s 460(3), (7), (10) allowed the police to apply to a judge for an additional six hour period, but only with the consent of the accused.

99 Crimes (Custody and Investigation) Act 1988) (Vic), s 464A. Whether the courts will deem "a reasonable time" to give the police more leeway than "as soon as practicable" remains to be seen.

100 Compare $R v$ Stafford (1976) 13 SASR 392 (Full Court) and Walker v Marklew (1976) 14 SASR 463, 467 per Bray CJ, 475 per Jacobs J, 482 per King J (excluding the confession, in part, due to an illegal arrest), with $R \vee$ Banner [1970] VR 240, 249 (Full Court) and $R \vee$ Lavery (No.2) (1979) 20 SASR 430 (admitting the confession). 
the grounds for exclusion of a confession, then so should custody that was illegal at its inception. ${ }^{101}$

Beyond these cases, Australian law exhibits only sporadic examples of evidentiary exclusion, usually by single state Supreme Court trial justices that can, in no sense, be considered to state a 'rule' that is generally applied by the courts of that state, much less the country. For example, in $R v$ Soundry ${ }^{102}$ the judge excluded a confession where the police had given "deliberately false answers" to solicitors who called the police to locate an accused. And, in the unusual case of $R v A_{\text {mad }}{ }^{103}$ a confession was excluded on the ground that it was obtained by a mild 'cross-examination' of a suspect in custody. ${ }^{104}$

By contrast, there are numerous cases where the courts have refused to exclude evidence despite rather extreme examples of police misconduct. The most important of these is the recent High Court case of Van der Meer $v R .^{105}$ In Van der Meer the five Justices who decided the case unanimously condemned the police interrogation techniques, the majority describing them "rather bizarre"106 (though never flatly terming them illegal). Yet, by a 3 to 2 majority the court held that the trial judge had not misapplied the principles relevant to determine whether to exclude the suspects'admissions. ${ }^{107}$ The disapproved procedures included confronting a suspect with the victims, and noting his responses to their accusations, the effect of which was "virtually to put [the suspect] on trial" at the police station. ${ }^{108}$ Also, the police, during an interrogation that began about 10.00 am and continued sporadically until about midnight, engaged in conduct which Mason CJ described as "persistent confrontation of each [suspect] with the alleged statements of the other [suspects] in an endeavour to break down his denial of guilt and the absence of any caution to [two suspects] until late in the interrogation". ${ }^{109}$ The majority

101 In America, exclusion in such a case is mandatory, Brown $v$ llinois 422 US 590, 603 (1975) unless intervening factors, such as release from custody or consultation with a lawyer, have broken the causal connection between the illegal arrest and the confession. Miranda warnings alone will not do this: Dunaway v New York 442 US 200 (1979).

102 Queensland Supreme Court, 26 March 1980, unreported decision of Macrossan J cited in

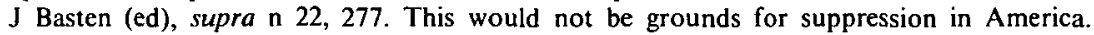
In Moran v Burbine 475 US 412 (1986) the police had told the defendant's lawyer that they would not be questioning him that night. They did question him and he confessed. The Court, while indicating its "distaste for the deliberate misleading of an officer of the Court", held that "nothing in the Constitution vests in us the authority to mandate a code of behaviour for state officials" and that this behaviour in no way amounted to compulsory self-incrimination.

103 [1962] VR 545.

104 Cf $R v$ Von Aspern [1964] VR 9I, 93 per O'Bryan J taking a broader view of police powers to interrogate. As the High Court put it in $R v$ Lee (1950) 82 CLR 133, 155 :

[A]n invitation to explain established facts can hardly be called cross-examination in any relevant sense. It is cross-examination in the sense of breaking down the will and extorting admissions by persons who are being questioned by the police that is to be reprehended.

Amad must be regarded as an aberration.

105 (1988) 82 ALR 10.

106 Ibid 25 per Wilson, Dawson and Toohey JJ.

107 lbid 28-29.

108 lbid 25.

$109 \mathrm{lbid}$ 17. This latter factor was not condemned by the majority which held that the caution is not required until the police are "satisfied that [they have] a case against [a suspect]": ibid 25. 
further brushed off the fact that, when one of the suspects [Ayliffe] finally was cautioned and asked if he was prepared to answer further questions he replied "No, not really", and "I'm not saying nothing". Despite this, he was encouraged to, and did, respond to what the police told him his fellow suspects had said. ${ }^{110}$ Oddly, none of the opinions discussed the Ireland (deterrence of police misconduct) discretion. The majority confined itself to the reliability issue and, concluding that the statements were reliable, admitted them. "II

In $R v$ Banner 112 a suspect was arrested without reasonable suspicion, held incommunicado and interrogated by the police over a period of three days without being taken before a magistrate. The Victorian Supreme Court, while strongly condemning the police behaviour and declaring them "guilty ... of unlawful acts" and "possibly criminal conduct" 13 nevertheless admitted his confession to murder into evidence. ${ }^{1 / 4}$

In $R \vee S$ and $J^{15}$ the statutory requirement that arrestees be brought "forthwith" before a magistrate was avoided by the simple expedient of not formally arresting the sixteen year-old Aboriginal suspects until after "many hours" of interrogation. ${ }^{16}$ The two suspects were taken separately to police headquarters and, though they were told they were "not under arrest", the police admitted that they would have arrested them had the suspects not

110 Ibid 18 per Mason CJ; 31 per Deane J. Justice Deane described this case as "an example of how police investigations should not be conducted in this country."

111 Eg, ibid 26 per Wilson, Dawson and Toohey JJ: "[T]he question is not whether the police have acted unfairly; the question is whether it would be unfair to the accused to use his statement against him. [That is, was that] statement obtained in circumstances which affect [its] reliability ...". This failure to discuss the Ireland discretion in Van der Meer suggests ambivalence on the part of the High Court as to what its stance should be toward excluding evidence to deter police misconduct. One possible explanation for this failure could be that the court, apparently, found no statutory violation by the police and hence their conduct was not technically 'unlawful'. However, in Bunning $v$ Cross (1978-79) 141 CLR 54, 71 per Stephen and Aickin $\mathbf{J} \mathbf{J}$ made it clear that this head of discretion applied to both 'unlawful or improper conduct' by police. Certainly it would make no sense to exclude evidence to deter the mild violation of telling a suspect that he had to have his hands photographed but not to exclude it in a case of police brutality simply because there was no statute explicitly forbidding this.

112 [1970] VR 240 (Full Court).

113 Ibid 249. The court noted that, during the first 15 hours of detention, before the suspect gave his first confession, the police did not even have reasonable grounds for suspecting him of any crime, or that a crime had even been committed.

114 Ibid 251-252. The court, as in Van der Meer, held that it was not 'unfair' to use the confession. However, this case was decided before Ireland, where the 'deterrence of police misconduct' head of discretion was established. See $R v$ Larson and Lee [1984] VR 559, a more recent Victorian case excluding evidence in a case of similar, though less serious police misconduct.

115 (1983) 8 A Crim R 88.

116 Ibid 96 per White J, dissenting. 
agreed to go to the police station and "the suspects believed that that would be the result of non-compliance". 117

\section{(4) No Exclusion due to Illegal Searches}

While the Australian law as to exclusion of confessions on any of the grounds set forth by the High Court can charitably be described as erratic, it is at least apparent that courts are alive to the possibility that they can, through enforcement of exclusionary principles, put pressure on the police to follow the rules, if only there were more clearcut 'rules' to follow. In contrast to this is the total failure of Australian courts ever to exclude the fruits of an illegal search from evidence in a criminal trial. ${ }^{18}$ Every state has statutory rules governing searches ${ }^{119}$ that are similar to the American rules and in numerous cases the courts have struck down warrants and ordered the evidence returned due to failure to set forth reasonable grounds in the application, and for overbreadth, etc. ${ }^{120}$ However, these decisions do not necessarily preclude the police from proceeding with a prosecution and re-

117 Ibid 94 per Mitchell $\mathrm{J}$. The police also failed to have a parent, guardian or representative of the Aboriginal Rights Movement present at the interrogation as required by police instructions: ibid 91. Contra, $R \vee W$ and others [1988] 2 Qd R 308 where, on virtually identical facts, a Queensland trial judge excluded confessions of Aboriginal juveniles as both involuntary and unfair.

In $R \cup$ Byczko and McCloud (1982) 30 SASR 578 the fact that the defendants were "detained without lawful authority" and believed that they were not free to go (one even had his overalls taken away by the police) was not sufficient to require exclusion of a confession: ibid 584. This, despite the court's conclusion that "the infringement of the appellant's legal rights was undoubtedly serious": ibid 585. To the same effect is $R v$ Narula (1986) 22 A Crim R 409: illegal delay in arraignment - no exclusion of confession.

118 "[A]s far as $\mathrm{I}$ am aware there has not been any significant or reported case in which evidence has been excluded because of the illegality of the means of its production." (Letter to author from Prof Peter Sallmann, 18 May 1989.) See eg Gillies, supra n 24, 241. Gillies cites three Australian cases in support of the proposition that "when real evidence has been improperly or unlawfully obtained ... the trial judge [may] exercise his discretion to reject it". In all three cases, the evidence was, in fact, admitted. Mclntyre $v$ Sing (1979) 30 ALR 299; Crowley v Murphy (1979) 28 ACTR 1; Trimboli v Onley (1981) 37 ALR 38. Ireland and Ex $p$ Weldon (1971) 2 NSWLR 294, involving illegal seizures, but not searches, are the only cases I discovered involving exclusion of real evidence on any ground. Even evidence obtained by an illegal wiretap is admissible in cases punishable by more than three years imprisonment: P Gillies, ibid 289-290, citing the Telecommunications Act 1975 (Cth) s 7. However, the High Court has held that documents which would not be admissible in Court anyway, due to legal professional privilege, may not be seized pursuant to a search warrant: Baker v Campbell (1983) I53 CLR 52; Arno v Forsyth (1986) 65 ALR 125 (Full Federal Court).

$119 \mathrm{Eg}$ the Crimes Act (1900) (NSW), s 357E provides for the stop and search of persons or vehicles reasonably suspected of "having or conveying any thing stolen or otherwise unlawfully obtained or any thing used or intended to be used in the commission of an indictable offence". The Search Warrant Act 1985 (NSW), ss 5 and 6 provides that search warrants may be issued on reasonable grounds for belief that there is, on any premises, "a thing connected with a particular [specified] offence" and that the warrant must specify the things to be searched. It further provides for the seizure of other evidence found on the premises ( $\mathrm{s} 7$ ), the search, on reasonable suspicion, of people found on the premises (s 8) and for telephonic warrants "in case of urgent need" (s 12).

$120 R$ v Optical Prescription Spectacle Makers Pty Lid (1986-87) 25 A Crim R 143 (Fed Ct of Aust); Parker v Churchill (1986) 9 FCR 334 (Fed Ct of Aust - Full Court); Hedges $\nu$ Grundman (1985) 19 A Crim R 303 (Sup Court of Qld - Full Court); Tran Nominees Pty Lidv Scheffler (1985) 20 A Crim R 287 (Sup Court of SA). 
obtaining the same evidence by subpoena. ${ }^{121}$ Moreover, all of these decisions are in warrant cases where the police are already making an effort to comply with the law. More in need of scrutiny are warrantless searches and seizures, but these appear to have largely escaped judicial notice. In one of the rare cases where this issue has been considered, in $R v$ Tilev, 122 the police entered a flat without a warrant and without reasonable suspicion and found significant evidence of a murder. The trial judge, while recognising his discretion to exclude the evidence under Bunning v Cross, refused to do so on the ground that the police conduct, while illegal, was not "wholly outrageous". ${ }^{23}$ Thus, despite the pronouncements of the High Court in Bunning $v$ Cross, Australian courts still seem to reflect the British view that "the interests of the state must excuse the seizure of documents, which seizure would otherwise be unlawful, if it appears in fact that such documents were evidence of a crime committed by anyone". 124 Discussions with Australian defence attorneys who were keenly aware of police violations in the confessions area did not reveal much concern about illegal searches. ${ }^{125}$ In part this could be explained by the high proportion of cases in which there is a confession - 96 per cent in one study. ${ }^{126}$ If the police can get a confession they will not feel as much need to search. Another explanation lies in the finding of the Law Reform Commission that "very many of the searches of premises undertaken by police officers are made ... at the 'invitation' or at least the consent of the occupier". ${ }^{227}$ Still, given the large number of cases involving suppression of illegally seized evidence in America, despite the presence of a consent doctrine there as well, ${ }^{128}$ it is inconceivable that there are not a significant number of cases involving evidentiary seizures by Australian police where the propriety

121 In fact in Hedges, supra $n$ 120, the court ordered the return only of private medical files seized by the police that had no relevance to a criminal case. The court explicitly did "not extend the order to other property seized at the time of the execution of the warrants in view of the pending criminal proceedings": ibid 304 per Campbell J, Connelly J concurring. This, despite the court's finding that the warrants in question were "bad on their face": ibid 303.

122 (1984) 33 SASR 344.

123 Ibid 352 per Wells J. See also Milner $v$ Anderson (1982) 42 ACTR 23 (evidence of a search of defendant's person admitted despite the lack of a reasonable suspicion or consent).

124 J Oxley-Oxland, NSW Police Law Handbook (1988) s 1806 quoting Elias v Passmore (1934) 2 KB 164. Oxley-Oxland opines, however, that if the police conduct were "oppressive ... it would not be right to allow the Crown to rely upon it."

$125 \mathrm{Eg}$ interview with public defender, 13 February 1989; interview with barrister, 23 February 1989.

126 N Stevenson, supra n 22, 108-109. This figure apparently was a percentage only of cases which resulted in conviction, whether by guilty plea or trial, and did not include dismissals and/or acquittal.

127 LRC Criminal Investigation, supra n 5 para 195. One study showed that, in a 6 month period in 1975, 62\% of the searches conducted by the (former) Narcotics Bureau and Customs Department were made by consent. The Commission recommended that a signed acknowledgement should be produced by police claiming consent "the absence of such acknowledgement being prima facie evidence" that the search was not consented to: ibid para 197. Obviously, it is believed by the Commission that the police are as willing to fabricate consents to search as they are confessions. In my study in America, I found that consents were advanced as a justification for the search in $17 \%$ (37 of 223) of the appellate case studied: C M Bradley, "Are the State Courts Enforcing the Fourth Amendment?" (1989) 77 Georgetown Law Jo 501, 508.

128 Schneckloth v Bustamonte 412 US 218, 223 (1973) (defendant need not be informed of his right to withhold consent). Nor need the consent be written. 
of the search (or the existence or voluntariness of the consent) should at least be discussed.

This impression is confirmed by two cases where the court's description of the police behaviour seemed to involve an illegal search, even though that issue was not discussed. In $R v$ Narula $^{129}$ the court, in discussing whether a confession was admissible, mentions that the heroin was located by the police during a "surreptitious search" of a hotel room. Since no search warrant is mentioned, I presume this was the result of an illegal entry. ${ }^{130}$ In another case, $R v$ Kushkarian, ${ }^{131}$ the appellant was arrested for possession of a sawedoff shotgun (and later charged and convicted of armed robbery) after the shotgun "was found [by police] in the back of his motor vehicle". ${ }^{132}$ There is no discussion of how the police came to look in the back of his vehicle, which was parked at his home.

A particularly striking example of both the relative rarity of, but also the lack of concern in the Australian legal system for illegal searches is provided by the Beach Report. ${ }^{133}$ There, twenty cases of gross violations of individual rights by the Melbourne police are set forth including false arrests, fabricated confessions and brutalising of arrestees. ${ }^{134}$ Only one of these cases involved a search at all. ${ }^{135}$ In that case the police, acting with reasonable suspicion but without a search warrant or in exigent circumstances, broke into a flat occupied by two suspects, pushed one of them out of a window to the street 30 feet below and brutalised him as he lay on the ground with broken limbs. Yet despite the obvious illegality of this search, the Board of Inquiry makes no mention of the fact that no warrant was obtained, but focuses instead on the subsequent police brutality. While this brutality was certainly the most important feature of the incident, it is still inconceivable that an American analysis of a similar incident would not point out, as a matter of first principle, the illegality of the warrantless entry.

\section{PROPOSALS FOR CHANGE}

As the cases discussed illustrate, and as Australians who have studied the system agree, "the "law' of criminal investigation in Australia is in a totally unsatisfactory state." 136 Despite this recognition, however, neither of the two major models of reform, the Law Reform Commission reports on Criminal Investigation (1975) and Evidence (1987), recommends the adoption of the

129 (1986) 22 A Crim R 409.

130 In America, at least, hotel employees may not consent to the search of a particular room during the period in which it has been rented by a guest. Stoner $v$ California 376 US 483 (1969). It is not clear what the Australian rule is, or whether any such consent was obtained in this case.

131 (1984-85) 16 A Crim R 416.

132 Ibid 417 per Street CJ.

133 Supra $\mathrm{n} 8$.

134 Ibid 31-49.

135 "The Sellers Matter", ibid $486 \mathrm{ff}$.

136 P Sallmann and $\mathrm{J}$ Willis, supra $\mathrm{n} \mathrm{1,40.} \mathrm{The} \mathrm{sanctions} \mathrm{currently} \mathrm{used} \mathrm{have} \mathrm{not} \mathrm{"been} \mathrm{particularly}$ effective deterrent[s] to overly enthusiastic law enforcement activity": LRC Criminal Investigation supra n 5 para 287. "The voluntariness rule suffers from many deficiencies": LRC Evidence supra n 8 para 156. 
American-style automatic exclusionary rule. ${ }^{137}$ This is so despite the Law Reform Commission's recognition that "[r]ights without remedies may be no more than rhetoric" and their awareness of, and recommendation of, many other aspects of the American system.

Why is an automatic exclusionary rule rejected when, by providing a relatively certain sanction for rights violations, it should have the effect of deterring (or at least tending to deter) such police misconduct? 138 The answer given by the Law Reform Commission is instructive to Americans. They point out that "the American rule has its limits". 139 They point to the ways in which the United States Supreme Court has cabined the operation of the exclusionary rule:

An accused person cannot invoke the rule if the evidence was obtained in breach of another's rights. The rule does not apply to breaches by a private individual rather than a state official. It does not apply so as to prevent the presentation of illegally obtained evidence to a federal grand jury. And the rule does not apply where the evidence is admitted not on the issue of the accused's guilt but on some collateral issue such as his credibility as a witness. This kind of narrow distinction between evidence proving guilt and evidence proving that an accused who says he is not guilty is not worthy of belief as a witness tends to bring the law and lawyers into contempt. ${ }^{140}$

The above are exceptions to the 'automatic' exclusionary rule, and are cases where the rule does not operate despite concededly illegal police behaviour. The other way that the United States Supreme Court has mitigated the seeming harshness of a rule that automatically excludes evidence in case of a violation, is by loosening the definition of what constitutes a 'violation'.141 For example, the Court has frequently declared that

The Fourth Amendment proscribes all unreasonable searches and seizures, and it is a cardinal principle that searches conducted outside the judicial process, without prior approval by judge or magistrate, are per se unreasonable under the Fourth Amendment - subject only to a few specifically established and well-delineated exceptions. ${ }^{142}$

137 LRC Criminal Investigation supra n 5 para 298; LRC Evidence supra n 8 para 164(a): "In the Commission's view, the policy concerns do not justify automatic exclusion. The policy concerns compete and operate with varying force depending on the circumstances of a particular case. The intention is one which a discretionary approach is the most appropriate ... [But] . . once misconduct has been established, the burden should rest on the prosecution to persuade the court that the evidence should be admitted".

$138 \mathrm{M}$ W Orfield, supra $\mathrm{n} 4$ finding that the exclusionary rule does deter police search and seizure violations. The former Attorney-General of Maryland agrees. United States $v$ Leon 468 US 897, 954 (1984) per Brennan J dissenting, n 13.

139 LRC Criminal Investigation supra n 5 para 292.

140 Ibid para 293. Another significant recent example of this is United States $v$ Leon supra n 138 where the Court held that a search pursuant to a defective search warrant would not lead to exclusion of the evidence since the mistake was that of the magistrate who issued the warrant, not that of the police. As long as the police acted in reasonable good faith reliance on the warrant, the exclusionary rule does not operate.

141 As the Law Reform Commission pointed out, "[the mandatory exclusionary rule] tempts courts to reduce the protection of the substantive search and seizure rules by holding no illegality has occurred in order to avoid important evidence being excluded": LRC Criminal Investigation supra n 5 para 295.

142 United States $v$ Ross, 456 US 798, 825 (1982) quoting Mincey v Arizona 437 US 385, 390 (1978). 
In fact, as I have previously pointed out, "these exceptions are neither few nor well-delineated". ${ }^{143}$ There are over twenty such exceptions and "searches conducted pursuant to these exceptions, particularly searches incident to arrest, automobile and 'stop and frisk' searches, far exceed searches performed pursuant to warrant". ${ }^{144}$ Thus, despite the 'warrant requirement', many searches conducted without a warrant are not 'illegal' and consequently, the exclusionary rule does not operate.

Of course, these kinds of exceptions are not necessarily inherent in a mandatory exclusionary rule. The Court could stick to a strict warrant requirement, and impose no 'standing' or 'use for impeachment purposes' limitations on the operation of the exclusionary rule, as the dissenting Justices have consistently urged. ${ }^{145}$ Justice White, dissenting in Rakas $v$ Illinois ${ }^{146}$ where the court affirmed the principle that a defendant could not get exclusionary relief if an illegal search had only violated another's rights (the 'standing' requirement), put the problem well:

If the Court is troubled by the practical impact of the exclusionary rule, it should face the issue of that rule's continuing validity squarely instead of distorting other doctrines in an attempt to reach what are perceived as the correct results in specific cases. ${ }^{147}$

Clearly, the Court's reluctance to have a clearcut rule that always applies is due, as White $\mathrm{J}$ intimated, to the Justices' recognition that this will lead to an unacceptably high number of criminals going free because the police blundered.

Is a discretionary rule, then, the only honest answer? Certainly the discretionary rule currently practised in Australia, which is "often mentioned but rarely acted upon"148 can hardly be considered an adequate safeguard to civil liberties. The Law Reform Commission's proposals to remedy this problem deserve serious consideration. They recommend that where the police have broken the rules in obtaining evidence, "the court shall not admit the evidence unless it is, on the balance of probabilities, satisfied (by the prosecution) $)^{149}$ that admission of the evidence would specifically and substantially benefit the public interest without unduly prejudicing the rights and freedoms of any person". Factors to consider include the seriousness of the offence, the seriousness of the police misconduct and the extent to which the evidence in question might have been lawfully obtained. ${ }^{150}$ A more recent Law Reform Commission report takes essentially the same view but deletes the 'substantially' provision, merely requiring that "the desirability of admitting the evidence outweighs the undesirability of evidence that has been [illegally] obtained." It also adds other factors to consider including

143 C M Bradley, "Two Models of the Fourth Amendment" (1985) 83 Mich L Rev 1468, 1473.

144 Ibid 1475.

145 See eg, Leon supra n 138, 928 per Brennan $J$ dissenting, where he terms the majority view an "abandon[ment of the] exclusionary rule . ..".

146439 US 128 (1978).

147 Ibid 157 per White $\mathrm{J}$ dissenting, Brennan, Marshall and Stevens $\mathrm{JJ}$ concurring.

148 LRC Criminal Investigation supra n 5 para 288. The Commission also termed the then current Australian practice as "a virtual non-exclusionary rule [which] tends to encourage illegality, and hence reliance on illegally obtained evidence rather than other evidence".

149 Currently the defendant bears the onus of convincing the Court that the discretion should be exercised in his favour.

150 LRC Criminal Investigation supra n 5, Appendix B Draft Legislation s 71. 
"the importance of the evidence in the proceeding" and "whether the impropriety ... was contrary to or inconsistent with a right of a person recognised by the International Covenant on Civil and Political Rights."'sı

The more recent proposal also imposes quite stringent requirements on the use of admissions obtained during interrogation of persons "reasonably suspected" of crime, ${ }^{152}$ declaring that they are "not admissible", (and would thus establish a mandatory exclusionary rule), unless the defendant is cautioned as to his right to silence and possible use of his statements against him and his admission is tape recorded.153 Admissions "influenced by violent, oppressive, inhuman or degrading conduct, whether toward the person who made the admission or toward some other person, or by a threat of conduct of that kind", are also (mandatorily) "not admissible". ${ }^{154}$

Certainly the recommendations concerning confessional evidence seem highly desirable. They will largely eliminate police fabrication of confessional evidence while, at the same time, by putting confessions on tape, increase their value in the prosecution's case. Indeed, in my view videotaping of confessions, where practicable, would be an even more desirable requirement. 155 The one thing missing from their proposal, evidently left out

151 LRC Evidence, supra n 8, Appendix A. Draft legislation s 119. Para 164(a) makes it clear that the onus of proof is to be on the prosecution.

152 Or who "ought to have been reasonably suspected" LRC Evidence, supra n 8, Appendix A. Draft legislation $s 74$. This is somewhat broader than the rather vague 'custody' requirement in the United States which does not, for example, apply to a brief detention of a motorist pursuant to a traffic stop: Berkemer v McCarty 468 US 420 (1984), or to a suspect who volunteers to come to the police station to talk about a crime: California $\vee$ Beheler 463 US 1121 (1983). Since both of these people were certainly 'reasonably suspected' of crime the proposed Australian rules would apply to them. It is not obvious to me that such a broad application is advisable, however.

153 LRC Evidence, supra $\mathrm{n} 8$, Appendix A. Draft legislation $\mathrm{s} 74$. If it was not reasonably practicable to have made such a recording of the actual admission, a recording of the suspect confirming the admission will suffice. The Commission report makes it clear at para 164(b) that signed records of interview are not a substitute for a tape recording despite a section in the Draft Legislation (s 75) which seems to suggest that they may be. The Review Committee on Commonwealth Criminal Law, Interim Report (February 1989) recently proposed similar rules, requiring tape recording and cautions as to both right to silence and counsel, but imposing a mandatory exclusionary rule only on non-tape recorded statements: ibid para $85 \mathrm{~F}(2), 85(\mathrm{c})(1)$ and $85(\mathrm{~T})(1)$.

A new Victorian statute, supra n 99 requires taping of any "confession or admission made to an investigating official by a person who was suspected or ought reasonably to have been suspected" of an "indictable offence" and provides, subject to exceptions, that unrecorded statements are "inadmissible". The statute further provides that a "person in custody" must be informed "that he or she does not have to say or do anything but that anything the person does say or do may be given in evidence" (s.464A(3)) and that such a person must be informed that he or she has a right to "communicate with a legal practitioner": $s 464 \mathrm{C}(1)$. However 'custody' does not begin unless the defendant is actually arrested or "there is sufficient information in the possession of the investigating officer to justify [an] arrest ..." (s $464(1))$. It is not clear whether unwarned, as opposed to untaped statements are inadmissible, since the statute also requires that the warnings be taped, ( $\mathrm{s} 464 \mathrm{G}$ ), but does not in terms provide that unwarned statements are inadmissible.

154 LRC Evidence, supra n 8, Appendix A Draft Legislation s 72.

155 Chief Justice Mason shares this view noting that videotaped confessions would expedite criminal proceedings: the Canberra Times, 21 March 1989, 10. While not requiring videorecording the Commission also made it clear that it was not prohibited: $L R C$ Evidence, supra n 8 , para $163(\mathrm{a})$. 
in deference to, or in fear of, the police lobby, ${ }^{156}$ is a limitation, similar to the former Victorian statute previously discussed, 157 on the amount of time a suspect can be held for questioning before being taken before a judge or magistrate. In my view, the maximum period should be six hours, extendable for six more hours by a judge or magistrate upon application by the police for good cause shown.

Currently, in America, once the courts are satisfied that the Miranda warnings have been given and that the statement has not been induced by force or threats, there is a tendency to ignore other concerns. Thus, as discussed, police falsely telling a suspect that his fingerprints have been found at the crime scene has been ignored by the Supreme Court ${ }^{158}$ and the prompt arraignment requirement of Mallory $v$ United States ${ }^{159}$ has never been extended to the states. Various police interrogation techniques designed to induce the defendant to confess, which were condemned by the Court in Miranda $v$ Arizona ${ }^{160}$ are now, apparently, permitted, so long as the defendant receives the required warnings, though studies have shown that the warnings do little to discourage suspects from making damaging admissions to police. ${ }^{161}$ Given that none but the most committed civil libertarian really wants to discourage criminal suspects from making admissions to the police, it seems sensible to focus on ensuring that such admissions are reproduced accurately in court, at least as much as whether they were made after warnings or in response to false promises. The proposed Bill achieves this in a way that American law does not.

The proposed discretionary exclusionary rule as to illegal seizures of evidence is more problematic. Certainly the Australian experience to date makes a compelling case against discretionary, and in favour of mandatory, exclusion ${ }^{162}$ (although the current mandatory Australian rule against involuntary confessions also does not seem to be producing very consistent results). On the other hand, the American mandatory rule has led to the courts waffling,

156 Personal communication, Mr Stephen Mason, Secretary and Director of Research, Law Reform Commission, 2 March 1989. The police lobby has been highly influential in opposing and defeating previous efforts at reform. "The Victorian Police responded to the findings [of the Beach Inquiry] with remarkable vigour and hostility, and fought a largely successful campaign . . . to prevent the implementation of its procedural recommendations": Sallmann and Willis, supra $\mathrm{n} \mathrm{I,} 18$.

In response to the Criminal Investigation Bill of 1981, the President of the Police Federation of Australia and New Zealand threatened a police strike if the procedural protections of the bill were enacted. Senator Evans (then Attorney-General) "suggested that the police response to the Bill ... demonstrated 'a profound indifference to the constraints of existing law' ": Reform (April 1982) 63.

157 Supra n 99.

158 Oregan v Mathiason 429 US 492 (1977).

159354 US 449 (1957).

160384 US 436, 452 (1966), condemning for example the 'Mutt and Jeff' technique where one questioner who is mean to the suspect is replaced by another who is warm and sympathetic. Indeed, there is no reason to believe that the 'trial at the police station', condemned by the High Court in Van der Meer (1988) 82 ALR 10, would be illegal in the United States so long as the warnings were given.

161 See studies discussed in G M Caplan, "Questioning Miranda" (1985) 38 Vand L Rev 1417, 1455-1476.

162 See, Y Kamisar, W R La Fave and J H Israel, Modern Criminal Procedure (6th ed 1986) 521-524 and material cited therein discussing the inadequacy of the pre-Miranda 'voluntariness' test in the United States. 
and hence to creating confusion, as to the rules which, if broken, require exclusion.

This much can be said for a non-mandatory rule: as a matter of deterrence, it is surely not necessary to exclude evidence every time the police err. If the police knew that the evidence would be excluded for say two-thirds of the time, they would probably be just as deterred from illegal searches as they are now. The trouble with this approach is that it has to be random. Otherwise, whatever the standards, the police will learn them and adjust their conduct accordingly. Thus a standard, as proposed by the Law Reform Commission, of considering the seriousness of the case will tend to have little or no deterrent effect in serious cases because the police will know in advance that almost anything they do will not lead to loss of evidence. It is hard to imagine that merely shifting the burden of proof to the prosecution will cause judges, who have never, or virtually never, excluded evidence on the basis of an illegal search, to suddenly begin doing so with enough regularity to ensure police compliance with the rules.

As a supplement to its discretionary rule, the Law Reform Commission urges the creation of an external police review board to discipline the police for rights violations. ${ }^{163}$ The Commission believes that the combination of this board and its discretionary exclusionary remedy will cause the rules of criminal procedure to be "taken very seriously indeed". 164 I disagree, for two reasons. First, it is highly doubtful that convicted criminals or their lawyers will be motivated to bring, and be successful if they do bring actions before such a board. Such a board seems most useful as a supplement to a mandatory exclusionary rule, to vindicate the rights of innocent people aggrieved by police misconduct, rather than as a substitute for such a rule. Secondly, it seems unlikely that the police department, not facing loss of evidence due to officers' misconduct, would take the disciplinary recommendations of such a board very seriously. As Professor Amsterdam has observed:

Realistically, no extra-departmental body has the information, resources and direct disciplinary authority necessary to control the police effectively and consistently. 165

Consequently, I urge mandatory exclusion, despite its problems, as the only remedy likely to deter police misconduct. If one has a standard of forbidding unreasonable searches and seizures, as Australia clearly does, then it makes no sense to say to the police - 'Well, you weren't supposed to have conducted this search because you lacked reasonable grounds (for example), but, since you did it, we'll allow you the full benefit of the evidence. But don't do it again!' It is not the exclusionary rule, but the prohibition against unreasonable searches that forbids the use of the evidence. When such illegally seized evidence is offered in court, it is incumbent upon the judge to refuse it. This is necessary, as the High Court has recognised, in order to "discourage the use of unacceptable methods" by the police. ${ }^{166}$ Only when a penalty is consistently attached to police rights violations will such discouragement occur. The American experience has shown, moreover, that

163 LRC Criminal Investigation, supra n 5, para 301-302; Australian Law Reform Commission Report No 1 Complaints Against Police (1975) Appendix F.

164 LRC Criminal Investigation, supra n 5, para 301-302.

165 A G Amsterdam, "Perspectives on the Fourth Amendment" (1973-74) 58 Minn L Rev 349, 428; H Goldstein, "Administrative Problems in Controlling the Exercise of Police Authority" (1967) 58 Jo Crim Law, Criminology and Police Science 160, 161-162.

166 Cleland v $R(1982-83)$ I5I CLR 1, 31 per Dawson J. 
police can learn to follow the rules in most cases such that evidence need not be excluded very often in order to enforce the rules. One survey of studies showed that the rule results in the non-prosecution or non-conviction of between 0.69 per cent and 2.35 per cent of individuals arrested for felonies, 167 despite the fact that the American 'rules' can be bafflingly complicated. If the police in America were given straightforward statutory rules that a policeman of ordinary conscientiousness and ability could follow, the rate of evidentiary exclusion would surely drop even more. The Australian Law Reform Commission has achieved this in the confessions area with essentially, two simple commands to the police: (i) caution all suspects and (ii) tape record all statements. ${ }^{168}$

In the search area, the problem is not so much the rules, but the failure to enforce them. The New South Wales statutory scheme previously discussed ${ }^{169}$ sets forth fairly clearly the obligations of the police as to searches and seizures. ${ }^{170} \mathrm{I}$ cannot believe that violations do not occur and urge that these be discouraged by a consistent policy of evidentiary suppression (especially in cases where no warrant was obtained). Still, I believe that, in part, the absence of case law in the search and seizure area may be due to the existence and clarity of the statutory rules. If similar rules can be adopted and enforced as to confessions, Australia will have gone far down the road to achieving the dual goals of the criminal justice system apprehension of the guilty while protecting individual rights.

If, however, history repeats itself and the Commonwealth and State Parliaments fail to act then it is up to the High Court, acting as in Ireland under the authority of the common law or, on the basis of a statutory violation, to fill the breach and ensure police observance of traditional human rights by commanding the courts to refuse to admit evidence obtained in the violation of those rights or of statutory mandates. ${ }^{171}$ The fact that Australia does not have a Bill of Rights is irrelevant, as the High Court implicitly recognised in Ireland and Bunning $v$ Cross. Nothing in the American Constitution requires the exclusion of evidence obtained in violation of constitutional rights. The exclusionary rule is a judicial innovation developed by the Supreme Court as a means of ensuring that police and courts respect those rights. If Australia

167 Davies, "Hard Look at What We Know (and Still Need to Learn) About the "Costs" of the Exclusionary Rule" (1983) Am Bar Foun Res Jo 611, 621.

168 As discussed, supra text at n 155 . I would amend this only slightly by stating 'videotape all confessions' and by adding a third requirement that suspects not be held for questioning more than six hours without the approval of a judicial officer.

169 Supra $\mathrm{n} 119$.

170 One problem with the NSW statute is that it fails to limit police searches incident to arrest, which, under the common law, extends to the entire house of the arrestee. Gillies, supra n 22, 212. See Chimel v California 395 US 752 (1969) restricting these searches in America.

171 That the High Court has this power, subject to overruling by Parliament, seems undisputed: McDermott v $R$ (1947-48) 76 CLR 501. In Van der Meer (1988) 82 ALR 10, 18 per Mason CJ said that " $[\mathrm{t}]$ he common law balances a) the need to allow the police freedom of action in the investigation of crime in order to ascertain the wrongdoer and b) the need to ensure that a suspect is fairly treated and his right to silence protected". See too F A Allen, "The Judicial Quest for Penal Justice: The Warren Court and the Criminal Cases" [1975] U III L Forum 518, 525, suggesting that the failure of legislative bodies to act in this area is what made the United States Supreme Court step in. 
is to continue to claim that its citizens have rights with respect to the police, then it must back up that claim with remedies for rights violations. ${ }^{172}$

172 Chief Justice Mason recently recognised, reflecting the earlier statement of the Law Reform Commission, that "there can be no respect for a system of justice which pays lip service to certain rights and then does nothing to ensure that they are enforced ..." Opening Address, Conference of the Society for the Reform of the Criminal Law, 19 March 1989, 13. 